By CARL W. E. HINTZ

\title{
Farmington and Beyond
}

$\mathrm{T}$ HE importance of the free flow of cultural, educational, and scientific information as one of the critical needs of the postwar world is accepted by informed circles to such an extent that its desirability seems scarcely debatable. The ThreePower Statement on Atomic Energy, issued in November 1945, the Constitution of the United Nations Educational, Scientific, and Cultural Organization, and the proceedings of the Conference on International Cultural, Educational, and Scientific Exchanges held at Princeton University, Nov. 25-26, 1946, all provide supporting testimony. Desire and accomplishment, however, are two entirely different things. As Downs' recent article in Science $^{1}$ points out, there are many obstacles to overcome before a logically planned and efficient system of interchange can function.

Closely allied to the desirability of a free exchange of materials is the essential need of securing complete coverage of publications from all parts of the world. This problem came into sharp focus during World War II when it was realized that many publications of military and research value were not to be found in any American library. The Farmington plan, projected by the Librarian of Congress and the librarians of Harvard and Princeton in 1942 and now well on the way toward being put into operation, is an attempt to prevent a continuance of this situation by arranging for the acquisition of at least one copy of every publication of research interest by some American library.

1.Downs, Robert B. "International Exchanges." Science 105:417-21, Apr. 25, 1947 .
Before the free flow of material envisaged by UNESCO and the Princeton conference and before the complete coverage contemplated by the Farmington plan can be fully accomplished, there are certain difficulties which must be attacked. One of the principal obstacles is the lack of information concerning the publishing output of various countries, as few nations have an adequate national bibliography. This is particularly serious in the case of society and institutional publications which are not listed in the normal channels of the book trade. To overcome this defect and to achieve reasonably complete coverage is a bibliographical task which, according to Downs, will require the fullest "cooperation of UNESCO, the International Federation for Documentation, national governments, national libraries, library associations, pertinent commercial organizations, and any other agencies having an interest in finding a satisfactory solution."

Without unduly laboring the point, it seems obvious that the problem, and the task, is a major one. What, if anything, can the libraries of the United States do to further its attainment? It would seem that nothing short of a considerable change in methods of acquisition will meet the situation.

By and large, the materials acquired by research libraries fall into two major categories:

I. Materials available through the book trade, which are apt to be listed in trade bibliographies and catalogs.

2. Materials issued by institutions, foundations, societies, and other organizations, which 
are outside the regular channels of the book trade. They are frequently not listed in national bibliographies, are not produced for profit, and are difficult to locate and acquire. Nevertheless, they form an important bloc of material.

Libraries in general have tended to handle acquisitions in terms of the above divisions. Materials in the trade have been bought through dealers who have, of course, made some profit on the transaction, while the second group has been acquired in a variety of ways usually involving considerable individual effort.

Instead of separating our acquisitions into two distinct groups, as in the past, would it not be possible to combine them so that the profit on the commercial material could finance the bibliographical work needed to handle the noncommercial material? In this way it would not be necessary to seek the aid of foundations or governmental agencies nor would it be necessary to depend upon the cooperative goodwill of the participating libraries on such a large scale. It is true, of course, that the profitable finances the unprofitable to some extent through trade channels now, as dealers handle some noncommercial items on a service basis or as a convenience to their regular customers without charge.

The answer seems to lie in some form of cooperative acquisitions machinery. Although librarians have been noted for their cooperative outlook and have contributed much toward the completion of such monumental bibliographical tools as the Union List of Serials, cooperative buying has not reached any considerable degree of development. The most successful example of cooperative buying to date was that conducted in connection with the Carnegie Corporation grants to college libraries. ${ }^{2}$ The bibliographical center at Denver has

\footnotetext{
${ }^{2}$ Bishop, William Warner. Carnegie Corporation and College Libraries, I929-1938. New York, Carnegie Corporation, 1938.
}

acted as a purchasing agency for libraries in its general region and the Consumers' Book Cooperative, operating under the New York State Cooperative Law, served a large group of libraries in many states. ${ }^{3}$ It seems safe to say, however, that cooperative purchasing in the past has had as its objectives greater discounts and the elimination of unnecessary duplication and has not gained widespread acceptance at the best.

\section{A Cooperative Organization}

In order to perform the broader work contemplated, however, a new type of organization, modeled along the lines of a consumers' cooperative, seems necessary. It would differ, fundamentally but beneficially, from previous cooperative organizations in that it would have as one of its primary purposes the performance of bibliographical tasks rather than securing of larger discounts. In order to do this, profits would be plowed back into the business in order to finance the bibliographical work.

As far as its establishment is concerned, it might be possible to secure a grant from one of the foundations to finance the initial organization. If not, perhaps the participating libraries could provide the initial capital by purchasing shares as in the business or industrial world. Once in operation, profits would be used to finance bibliographical projects.

Such an organization would need to have a central office preferably in a center where bibliographical facilities and publishers were concentrated. New York City would meet this specification. American book production could be handled here. As far as foreign material is concerned, it would be necessary to select an agent or agents in each

Barcus, Thomas R. Carnegie Corporation and Col lege Libraries, 1938-1943. New York, Carnegie Corporation, 1943 .

${ }^{3}$ Wilson, Louis R., and Tauber, Maurice F. The University Library. 'Chicago, University of Chicago Press, 1945, p.62. 
country much as the Farmington plan now contemplates. In addition, however, provision must be made for furthering the bibliographical projects. It is suggested here that present organizations be utilized whenever possible if they already exist. ${ }^{4}$ It may be argued that this is not a new proposal, but the plan differs essentially from any existing suggestions in that there would be a full-time staff which, even though small, could devote more time and effort to coordinating existing projects and endeavoring to promote new ones than could any voluntary worker or group of workers.

The success of the plan depends upon the willingness of libraries to concentrate their buying with the new organization. Metcalf has stated ${ }^{5}$ that cooperative buying is apt to interpose another step between publisher and library and hence may increase cost and lengthen the time of delivery. However, many libraries now buy through a dealer rather than direct from the publisher. The proposed organization then would not interpose an additional step but would supplant the present intermediary, the jobber or dealer.

Based upon the experience gained through centralized purchasing in connection with the Carnegie Corporation grants to college libraries, it is not too much to hope a cooperative organization of this kind could be highly profitable and, after a period of operation, would be able to give the same schedule of discounts and still have a surplus for bibliographical projects. According to Bishop, ${ }^{6}$ over a million dollars' worth of purchases for eighty-one colleges were handled at a total expense to the Carnegie Corporation of less than

4e.g. The machinery whereby such services as Biological Abstracts and the Zoological Record now secure their material for listing.

${ }^{5}$ Metcalf, Keyes D. "The Essentials of an Acquisition Program." The Acquisition and Cataloging of Books. William M. Randall, ed. Chicago, University of Chicago Press, r940, p.9r.

"Bishop, William Warner. "Centralized Purchasing for American College Libraries." Library Quarterly 7:465-70, October 1937 .
$\$ 30,000$ and at a saving of at least $\$ 150,000$ to the colleges. Overhead in this case was admittedly low because the University of Michigar generously provided the necessary space. Barcus ${ }^{7}$ reported on the continued success of the program for teachers and Negro colleges and placed the overhead at about 4 per cent, excluding quarters.

The savings effected by pooling orders has already been referred to in the full realization that the material acquired was mostly in the trade. But why should not a pooling of orders for nontrade materials prove equally as economical?

\section{Greater Farmington Plan}

In other words, the proposal here hastily outlined is a variety of "Greater Farmington Plan" which would not only arrange for fields of specialization, and the acquisition of materials therein, but would also operate as a purchasing organization on a nonprofit basis. The parallel with a consumer's cooperative is clear-the corporation is owned by the stockholders, profits are used to expand the business (bibliographical projects) or are returned to the owner-customers on a patronage return basis (the larger your purchases, the greater your return).

The advantages of such a plan are that it would contribute materially toward the twin objectives of securing a free flow of material and complete coverage. By making the profitable finance the unprofitable and by eliminating much of the costly duplicative activity carried on by research libraries in their efforts to find out what has been published and where it may be obtained, there should be a considerable amount of money available for bibliographical projects which would otherwise be dependent upon voluntary cooperation or outside help.

\footnotetext{
7 Barcus, op. cit.
} 